\section{Quality and Nutritional Compounds of Prunus Cerasus L. Var. Austera Fruit Grown in Central Italy}

\author{
Simona Proietti, Stefano Moscatello, Fiorella Villani, \\ and Federica Mecucci \\ Istituto di Ricerca sugli Ecosistemi Terrestri (IRET) Consiglio Nazionale \\ delle Ricerche (CNR), 05010 Porano (TR), Italy
}

\author{
Robert P. Walker and Franco Famiani \\ Dipartimento di Scienze Agrarie, Alimentari e Ambientali, Università degli \\ Studi di Perugia, Via Borgo XX Giugno 74, 06121, Perugia, Italy
}

\section{Alberto Battistelli ${ }^{1}$ \\ Istituto di Ricerca sugli Ecosistemi Terrestri (IRET) Consiglio Nazionale delle Ricerche (CNR), 05010 Porano (TR), Italy}

Additional index words. Morello sour cherry, anthocyanins, bioactive compounds, flesh dry matter, malic acid, sugars

\begin{abstract}
Key nutritional characteristics of the fruit flesh of 41 sour cherries growing in the region of Umbria in central Italy have been determined. Fruit size, flesh dry matter content, nonstructural carbohydrates, organic acids, and anthocyanins were the analyzed parameters. Both the growing environment and genotype were statistically significant for most of the characteristics. Morello sour cherries were characterized by a large amount of sorbitol (up to $44.2 \mathrm{mg} \cdot \mathrm{g}^{-1} \mathrm{FW}$ ), which contributed significantly to the dry matter content of the flesh, malic acid content that was higher (up to $48.4 \mathrm{mg} \cdot \mathrm{g}^{-1} \mathrm{FW}$ ) than any published values for cherry flesh, and high anthocyanin content (up to $383.4 \mathrm{mg}$ per $100 \mathrm{~g}$ FW). Cyanidin 3-glucosyl rutinoside was the most abundant compound. The analyzed germplasm could be the basis for breeding programs and new industrial products with high nutritional value.
\end{abstract}

The term "cherry" identifies a group of species belonging to the genus Prunus within the family Rosaceae that is native to Europe and Western Asia (Stéger-Máté, 2012). Sweet cherry (Prunus avium L.), the most cultivated species, is grown for its fruit in temperate regions of the world. There are numerous cultivars of sweet cherry that have both nutritional and commercial importance. According to FAOSTAT (2017), the leading world producers in 2017 were Turkey, the Russian Federation, Ukraine, the United States, and Iran. There are three main cultivars of sour cherry, also known as tart cherry (Prunus cerasus L.): caproniana or amarella cherry, with light-colored flesh; marasca, with soft red flesh and a slightly tart flavor; and austera or Morello cherry, with dark red flesh and strong acidic juice (Stéger-Máté, 2012). Studies of sour cherry have rarely indicated the cultivar used, and this has

Received for publication 11 Feb. 2019. Accepted for publication 21 Mar. 2019

We thank Marcello Cherubini for his invaluable support with the germplasm sampling procedures. This study was supported by the FANP project [Frutti Antichi per Nuovi Prodotti (Ancient Fruit for New Products)] and grants from PSR Umbria 2007-2013.

${ }^{1}$ Corresponding author. E-mail: alberto.battistelli@ cnr.it. generated confusion regarding the characteristics of the flesh of each sour cherry cultivar, particularly the nutritional aspects.

The fruit of sour cherry is rich in nutritional components that are thought to be beneficial to human health (Chaovanalikit and Wrolstad, 2004; Mikulic-Petkovsek et al., 2016; Siddiq et al., 2011). The consumption of sour cherry has been reported to decrease the risk of certain cancers, decrease arthritic pain, decrease systemic and local inflammation, and decrease the risk of type 2 diabetes and certain cardiovascular diseases (McCune et al., 2011). In addition to several important dietary components, such as fiber, carbohydrates, minerals, and organic acids (Mikulic-Petkovsek et al., 2016), the fruit from the genus Prunus is a source of various phenolic compounds, (Blando et al., 2004; Kołodziejczyk et al., 2013; Siddiq et al., 2011). These metabolites are abundant in sour cherries, reaching values more than $80 \mathrm{mg}$ per $100 \mathrm{~g} \mathrm{FW}$ (Ballistreri et al., 2013; Blando et al., 2004). Furthermore, anthocyanins have high bioavailability in both fresh and processed fruit and largely contribute to the attractive red color of both the fruit and fruit products (McDougall et al., 2005; Toydemir et al., 2013).

The composition of the fruit is greatly dependent on genotype, environmental conditions, and agronomic and storage practices including anthocyanins and polyphenols
(Di Matteo et al., 2016; Di Vaio et al., 2015; Faniadis et al., 2010; Gonçalves et al., 2007; Kołodziejczyk et al., 2013). This has stimulated research aimed at obtaining knowledge of the effects of these factors on qualitative and nutritionally relevant characteristics of fruits and vegetables (Di Vaio et al., 2015; Kalt, 2006). However, for cherry, this type of research has largely been restricted to cultivars of sweet cherry (Di Matteo et al., 2016; Faniadis et al., 2010; Papapetros et al., 2018). Therefore, very little information is available regarding the influence of either the genotype or the growing conditions on the nutritional and industrial quality of sour cherry fruit from the cultivar austera.

The austera cultivar is commercially cultivated in Europe, particularly Hungary, Serbia, Turkey, and Poland (Stéger-Máté, 2012). In Italy, the austere cultivar was traditionally appreciated, and one tree or a small number of trees were grown on farms as a supplementary source of food before the modernization of agriculture. The fruit was and still is used for different traditional preparations (jams, conserves, or liquor), whereas the fresh fruit was and still is rarely consumed because of its acidic taste. Remnant plants from that time period are still the main source of fruit for personal and commercial use. Increasing interest from the food and beverage industry in sour cherry has encouraged the planting of sour cherry in orchards and conferred greater value to the traditional preparations for commercial use. However, it is difficult to industrialize sour cherry production due to the lack of a consolidated set of horticultural techniques, qualified and certified reproduction materials for the establishment of new orchards, and knowledge about what influences the quality characteristics needed for industrial use that meet the requirements for products rich in nutraceutical components (Di Vaio et al., 2015). In the case of the wine industry, for example, grape cultivation achieves the fruit quality required for the production of each specific type of wine. In the case of sour cherry, this type of organization for producing fruit in line with its industrial transformation is absent. Hence, because of the growing interest in sour cherry-based products, it is essential to increase our knowledge of the genetic characteristics and nutritional and industrial quality of Prunus cerasus L. var. austera germplasm.

The hypotheses of the present work were as follows: the sour cherry cultivar austera possesses distinct nutritional quality characteristics with regard to the caproniana and marasca cultivars; the germplasm of sour cherries present in different areas of central Italy (region of Umbria) has large variability in terms of nutritional quality parameters; the nutritional quality parameters can be affected by the genetic background and the growing environment; and the nutritional quality characteristics of the germplasm from central Italy could be exploited for industrial transformation of this highly valuable fruit.

The sour cherry cultivar austera was shown to possess distinctive compositional 
characteristics regarding the caproniana and marasca cultivars. Moreover, the germplasm available in central Italy possesses wide variability of key compositional traits. This germplasm can represent valuable material to boost the production and transformation of the fruit and to provide consumers with products with high nutritional value.

\section{Materials and Methods}

Plant material. In 2013, Morello sour cherries were collected from 41 individual scattered trees growing in different locations in the region of Umbria in central Italy. None of the sampled plants was grafted. The plants were mature, although the age was not tested and they were not part of commercial orchards. The locations of the plants were the Upper River Valley of the Tiber Tevere (northern Umbria), Valnerina (southeastern Umbria), Orvieto city area (southwestern Umbria), and the Amerini Hills (southern Umbria). The Upper River Valley of the Tiber Tevere (northern Umbria) is characterized by an annual average temperature of $\approx 13{ }^{\circ} \mathrm{C}$ and rainfall of $870 \mathrm{~mm}$. The Valnvaslerina (southeastern Umbria) is characterized by an annual average temperature of $\approx 13.5{ }^{\circ} \mathrm{C}$ and rainfall of $980 \mathrm{~mm}$. The Orvieto city area (southwestern Umbria) is characterized by an annual average temperature of $\approx 14{ }^{\circ} \mathrm{C}$ and rainfall of $850 \mathrm{~mm}$. The Amerini Hills (southern Umbria) is characterized by an annual average temperature of $\approx 14.5^{\circ} \mathrm{C}$ and rainfall of $930 \mathrm{~mm}$. The sour cherry trees sampled were all genetically tested and were shown to be the Morello (Prunus cerasus) species of botanical cultivar austera (Gaudet et al., 2018). As similarly performed for sweet cherry (Marchese et al., 2017), ripe fruit was collected from May to July. For each tree, three replicates with each consisting of seven fruits were collected and used for analysis. All fruit was picked when it was fully ripe and had dense, dark red skin. The fruit was immediately placed in liquid nitrogen and stored at $-80^{\circ} \mathrm{C}$ until analyzed. Supplemental Table 1 lists the trees and their geographical locations (i.e., height above sea level, latitude, and longitude). Each of these trees was also identified by fruit weight ranking from 1 to 41 using the fruit weight as the ranking parameter, with the rank code 1 given to the plant with the heaviest fruit. These ranking codes are used to identify each tree described here.

Fruit weight and chemical analyses (carbohydrates, polyols, and organic acids). Fruit weight refers to the weight of the whole ripe fruit without the stem. The fruit was coarsely ground in a mortar containing liquid nitrogen. The intact undamaged stones and the enclosed seed were manually removed, and the flesh plus skin (defined as flesh) was ground further to achieve a fine powder. The powder was used for all chemical analyses and for determining the percentage of dry matter (DM) (by lyophilization).
Sugars (glucose, fructose, sucrose, sorbitol, starch) and inorganic anions were determined by high-performance anion exchange chromatography using pulsed amperometric detection (ICS-5000; Dionex Thermo Scientific, Sunnyvale, CA). Organic acids were determined using the same method, but malic acid was determined using an enzyme-coupled spectrophotometric assay described by Walker et al. (2011). Sugars were extracted as described by Walker et al. (2011), and these extracts were then passed through a $0.2-\mu \mathrm{m}$ PPII syringe filter (Whatman Inc., Maidstone, UK). The sugars were then separated using an analytical CarboPac PA20 column $(3 \mathrm{~mm} \times 150 \mathrm{~mm}$, i.d. $5 \mu \mathrm{m})$ with a guard column in series and upstream of the aforementioned column.
Sugars were determined using a cell containing a gold working electrode (diameter, 1.0) together with an $\mathrm{Ag} / \mathrm{AgCl}$ reference electrode, and the resulting electrical signals were integrated to provide the values in nanocoulombs $(\mathrm{nC})$. Runs were performed at $30{ }^{\circ} \mathrm{C}$, and $\mathrm{NaOH}\left(10 \mathrm{mmol} \cdot \mathrm{L}^{-1}\right)$ was used as the mobile phase at a flow rate of 0.5 $\mathrm{mL} \cdot \mathrm{min}^{-1}$. A post-column addition of 300 $\mathrm{mmol} \cdot \mathrm{L}^{-1}$ of $\mathrm{NaOH}$ at a flow rate of 0.25 $\mathrm{mL} \cdot \mathrm{min}^{-1}$ was used. Inorganic anions were determined in the same extracts as those used for the sugar determinations with the same chromatographic system (ICS-5000; Dionex Thermo Scientific). However, for inorganic anion determinations, the system used a conductivity detector, an analytical IonPac AS11-HC column $(4 \mathrm{~mm} \times 250 \mathrm{~mm}$, i.d.

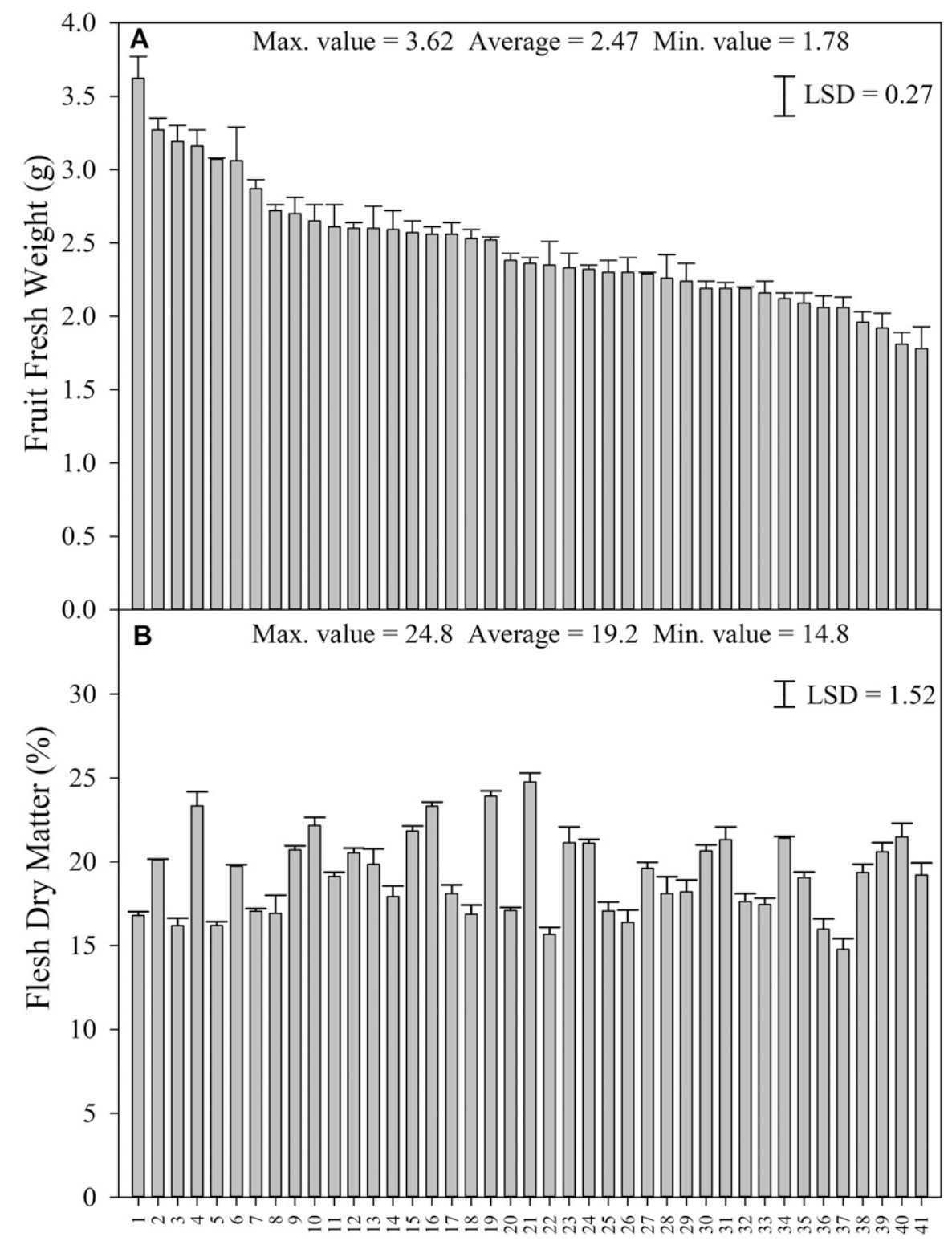

\section{Fruit Weight Ranking}

Fig. 1. Fruit fresh weight (g) (A) and flesh dry matter content (\%) (B) of sour cherry fruit collected in different geographical areas of the region of Umbria. Values represent the mean \pm SE. Data were analyzed according to a one-way analysis of variance. The bars indicate the least significant difference (LSD) between means according to Fisher's post-hoc test $(P \leq 0.05)$. 
$5 \mu \mathrm{m})$ with a guard column, and an IonPac ATC-1 (Anion Trap Column) coupled with an anion self-regenerating suppressor (all components were from Dionex Thermo Scientific). The electrical signal was integrated to provide the value in micro Siemens $(\mu \mathrm{S})$. Runs were performed at $30{ }^{\circ} \mathrm{C}$ at a flow rate of $1.0 \mathrm{~mL} \cdot \mathrm{min}^{-1}$. A sodium hydroxidestepped gradient was applied using $1 \mathrm{~mm}$ $\mathrm{NaOH}$ from 0 to 8 min, $15 \mathrm{~mm} \mathrm{NaOH}$ from 9 to $18 \mathrm{~min}, 30 \mathrm{~mm} \mathrm{NaOH}$ from 19 to $28 \mathrm{~min}$, $80 \mathrm{~mm} \mathrm{NaOH}$ from 29 to $39 \mathrm{~min}$, and $1.0 \mathrm{~mm}$ $\mathrm{NaOH}$ from 40 to $55 \mathrm{~min}$. Various compounds were determined using an external standard calibration curve. The eluents and standard solutions were prepared using high-performance liquid chromatography (HPLC) grade reagents (Sigma, Steinheim, Germany). Chromatographic data were reviewed using Chromeleon software version 6.8 .

HPLC analysis of anthocyanins. Anthocyanins were extracted according to the method of Usenik et al. (2008). Briefly, $100 \mathrm{mg}$ of frozen fruit flesh powder was extracted by adding $2 \mathrm{~mL}$ of methanol acidified with $1 \% \mathrm{HCl}$ and then placing it in an ultrasonic bath for $1 \mathrm{~h}$ at $25^{\circ} \mathrm{C}$. The extract was then filtered through a $0.2-\mu \mathrm{m}$ PPII syringe filter (Whatman Inc.). The anthocyanin content was then determined using an UltiMate 3000 HPLC system (Dionex Thermo Scientific) in conjunction with an ultraviolet-Vis detector. An Acclaim PolarAdvantage C16 column $(4.6 \times 250 \mathrm{~mm}$, i.d. $5 \mu \mathrm{m})$ was used to separate anthocyanins. This was performed at $30^{\circ} \mathrm{C}$ using a mobile phase gradient with two aqueous solutions of $10 \%$ formic acid (solution A) and $10 \%$ formic acid, $22.5 \%$ acetonitrile, and $22.5 \%$ methanol (solution B) at a flow rate of 0.7 $\mathrm{mL} \cdot \mathrm{min}^{-1}$. The gradient was formed with solution $\mathrm{B}$ at $18 \%$ from 0 to $1 \mathrm{~min}, 25 \%$ from 1 to $5 \mathrm{~min}, 50 \%$ from 5 to $15 \mathrm{~min}$, and at $18 \%$ from 15 to $20 \mathrm{~min}$. Anthocyanins in the extracts were identified using cyanidin 3sophoroside, cyanidin 3-rutinoside, cyanidin 3-glucoside, and peonidin 3-rutinoside standards, and they were quantified using an external standard calibration curve. Cyanidin 3-glucosyl-rutinoside was identified and quantified as described by Blando et al. (2004) using cyanidin 3-glucoside as a refer- ence. Chromatographic peaks were analyzed at a wavelength of $520 \mathrm{~nm}$. The eluents and the anthocyanin standards were prepared using HPLC grade reagents (Sigma and Extrasynthese, Lyon, France). Chromatographic data were processed using Chromeleon software version 6.8 .

Data handling and statistical analysis. First, all fruit data were analyzed as a unique pool, which made it possible to test the total variability of the germplasm. Second, the data from the four genotypes present in the growing area of the Amerini Hills were analyzed. This allowed testing of the genetic variability within the four genotypes. Third, data regarding fruit from plants growing in the five geographical areas and recognized as a single clone by genetic analysis (Gaudet et al., 2018) were analyzed. Hence, the environmental effects on one genotype were tested. Statistical analysis was performed using a one-way analysis of variance, and differences between the means were estimated by the least significant difference test $(P \leq 0.05)$. These analyses were performed using Statistics 8 (StatSoft for Windows 1998). In addition, the SE was calculated for each variable (see tables and figures).

\section{Results}

When the fruit from all genotypes was analyzed together, there were statistically significant differences between fruit fresh weights and flesh DM contents (Fig. 1A and B). The mean fruit fresh weight was $2.5 \mathrm{~g}$, and the maximum and minimum values were $3.6 \mathrm{~g}$ and $1.8 \mathrm{~g}$. The mean flesh DM content was $19.2 \%$, with maximum and minimum values of $24.8 \%$ and $14.8 \%$. There was significant variability between fruit fresh weight and flesh DM content of the different genotypes grown in the same environment (i.e., the "Amerini" Hills). Fruit fresh weight ranged from 2.4 to $3.2 \mathrm{~g}$, whereas the DM content ranged from $15.7 \%$ to $23.3 \%$ (Table 1). When the same genotype was grown in different areas, there were statistically significant differences in the fruit fresh weight and flesh DM content. Fruit fresh weight ranged from $2.1 \mathrm{~g}$ to $3.3 \mathrm{~g}$, whereas the flesh DM content ranged from $18.1 \%$ to $24.8 \%$ (Table 2).
The amounts of sucrose, glucose, fructose, and sorbitol and their total combined amount in the flesh of sour cherry fruit from all the different genotypes were determined (Fig. 2A-D). Starch and polyols other than sorbitol were undetectable or occasionally present in very low levels; therefore, their contents are not reported here. For all genotypes, glucose, fructose, and sorbitol, which are the main soluble carbohydrates (MSC), were present in large quantities. The amounts of many of these sugars and the total MSC were statistically significant between genotypes. Glucose ranged from 20.9 to 70.4 $\mathrm{mg} \cdot \mathrm{g}^{-1} \mathrm{FW}$ (Fig. 2B), and fructose ranged from 16.0 to $65.0 \mathrm{mg} \cdot \mathrm{g}^{-1} \mathrm{FW}$ (Fig. 2C). The genotypes that contained higher amounts of glucose also had higher fructose, and those with lower glucose had lower fructose; there was a significant correlation between the amounts of glucose and fructose $\left(R^{2}=0.85\right)$ (Fig. 2C inset). In general, sorbitol levels were lower than hexose levels $(\approx 38 \%$ lower, on average), and they varied between genotypes, with a range of 10.6 to $44.2 \mathrm{mg} \cdot \mathrm{g}^{-1} \mathrm{FW}$ (Fig. 2D). For a given genotype, sorbitol was correlated significantly with glucose and fructose $\left(R^{2}=0.72\right)$ (Fig. 2D inset). The amount of MSC varied from 48.9 to 175.5 $\mathrm{mg} \cdot \mathrm{g}^{-1} \mathrm{FW}$. The differences in the quantity of all carbohydrates in the flesh of the four genotypes grown in the same area (i.e., the "Amerini" Hills) were statistically significant (Table 1). The mean values of glucose, fructose, sorbitol, and total carbohydrates were, respectively, 52, 46, 28, and $126 \mathrm{mg}^{-\mathrm{g}^{-1}}$ FW. Glucose, fructose, sorbitol, and total carbohydrates in the flesh of the same genotype grown in different areas of Umbria showed statistically significant differences (Table 2). The average amounts of glucose, fructose, sorbitol, and total carbohydrates were $50,48,33$, and $131 \mathrm{mg} \cdot \mathrm{g}^{-1} \mathrm{FW}$, respectively. Absolute changes in the quantity of hexoses and sorbitol affected their relative abundance. The ratio spanned from a maximum of 4.7 to a minimum of 2.2. The ratio of different genotypes grown in the same environment showed statistically significant differences, but there were no differences in the same genotype grown in different environments. Ion-exchange chromatography showed that malic acid

Table 1. Qualitative parameters of sour cherry fruits collected from four trees from the Amerini Hills in the region of Umbria.

\begin{tabular}{|c|c|c|c|c|}
\hline \multirow[b]{3}{*}{ Geographic area } & \multicolumn{4}{|c|}{ Fruit weight ranking } \\
\hline & 4 & 8 & 13 & 22 \\
\hline & \multicolumn{4}{|c|}{ Amerini Hills } \\
\hline Fruit flesh weight (g) & $3.2 \pm 0.11 \mathrm{a}$ & $2.7 \pm 0.04 \mathrm{~b}$ & $2.6 \pm 0.15 \mathrm{~b}$ & $2.4 \pm 0.16 \mathrm{~b}$ \\
\hline DM \% & $23.3 \pm 0.84 \mathrm{a}$ & $16.9 \pm 1.09 \mathrm{c}$ & $19.9 \pm 0.91 \mathrm{~b}$ & $15.7 \pm 0.41 \mathrm{c}$ \\
\hline Glucose & $66.5 \pm 3.80 \mathrm{a}$ & $51.7 \pm 9.17 \mathrm{ab}$ & $53.9 \pm 5.45 \mathrm{ab}$ & $36.8 \pm 3.39 \mathrm{~b}$ \\
\hline Fructose & $60.3 \pm 1.93 \mathrm{a}$ & $41.4 \pm 7.07 \mathrm{~b}$ & $49.2 \pm 4.33 \mathrm{ab}$ & $34.6 \pm 3.67 \mathrm{~b}$ \\
\hline Sorbitol & $42.3 \pm 4.43 \mathrm{a}$ & $22.8 \pm 4.61 \mathrm{bc}$ & $29.9 \pm 4.34 \mathrm{~b}$ & $15.5 \pm 2.16 \mathrm{c}$ \\
\hline Total carbohydrates & $169.1 \pm 10.13 \mathrm{a}$ & $115.8 \pm 20.56 b$ & $132.9 \pm 14.12 \mathrm{ab}$ & $86.8 \pm 9.20 b$ \\
\hline Malic acid & $35.8 \pm 1.73 \mathrm{ab}$ & $38.1 \pm 3.81 \mathrm{a}$ & $30.4 \pm 1.57 \mathrm{~b}$ & $31.2 \pm 1.31 \mathrm{ab}$ \\
\hline Cyan. 3-sophoroside & $7.5 \pm 0.51 \mathrm{a}$ & $6.5 \pm 1.46 \mathrm{ab}$ & $10.3 \pm 2.27 \mathrm{a}$ & $2.6 \pm 0.71 b$ \\
\hline Cyan. 3-gluc rutinoside & $126.1 \pm 1.81 \mathrm{ab}$ & $84.4 \pm 20.91 b$ & $136.1 \pm 15.90 \mathrm{a}$ & $39.50 \pm 6.02 \mathrm{c}$ \\
\hline Cyan. 3-rutinoside & $4.9 \pm 0.10 \mathrm{ab}$ & $2.9 \pm 0.70 \mathrm{bc}$ & $6.1 \pm 1.35 \mathrm{a}$ & $1.6 \pm 0.25 \mathrm{c}$ \\
\hline Peonidin3-rutinoside & $42.4 \pm 0.25 \mathrm{a}$ & $25.7 \pm 4.78 b$ & $46.1 \pm 5.04 \mathrm{a}$ & $14.9 \pm 2.16 b$ \\
\hline Cyan. 3-glucoside & $3.5 \pm 0.07 \mathrm{a}$ & $2.5 \pm 0.25 b$ & $3.5 \pm 0.06 \mathrm{a}$ & $2.3 \pm 0.36 b$ \\
\hline Total anthocyanins & $184.4 \pm 2.03 \mathrm{a}$ & $122.0 \pm 28.01 \mathrm{~b}$ & $202.4 \pm 24.11 \mathrm{a}$ & $60.9 \pm 9.41 \mathrm{c}$ \\
\hline
\end{tabular}


Table 2. Qualitative parameters of sour cherry fruits collected from five genetically identical trees (Gaudet et al. 2018) collected at different sites in the region of Umbria.

\begin{tabular}{|c|c|c|c|c|c|}
\hline \multirow[b]{3}{*}{ Geographic area } & \multicolumn{5}{|c|}{ Fruit weight ranking } \\
\hline & 2 & 6 & 21 & 28 & 30 \\
\hline & Valnerina & Orvieto & Valnerina & Orvieto & $\overline{\text { Upper Tiber Valley }}$ \\
\hline Fruit flesh weight (g) & $3.3 \pm 0.08 \mathrm{a}$ & $3.1 \pm 0.23 \mathrm{~b}$ & $2.4 \pm 0.04 \mathrm{c}$ & $2.3 \pm 0.16 \mathrm{c}$ & $2.2 \pm 0.05 \mathrm{c}$ \\
\hline DM \% & $20.1 \pm 0.04 \mathrm{~b}$ & $19.7 \pm 0.09 \mathrm{bc}$ & $24.8 \pm 0.53 \mathrm{a}$ & $18.1 \pm 1.02 \mathrm{c}$ & $20.7 \pm 0.37 b$ \\
\hline Glucose & $39.6 \pm 18.57$ & $46.3 \pm 3.49$ & $65.5 \pm 3.13$ & $53.6 \pm 0.97$ & $46.3 \pm 0.88$ \\
\hline Fructose & $50.3 \pm 1.21 \mathrm{~b}$ & $38.6 \pm 3.36 \mathrm{~d}$ & $62.5 \pm 2.49 \mathrm{a}$ & $45.1 \pm 0.96 \mathrm{bc}$ & $43.2 \pm 0.56 \mathrm{~cd}$ \\
\hline Sorbitol & $33.4 \pm 0.96 \mathrm{a}$ & $33.6 \pm 2.60 \mathrm{a}$ & $38.7 \pm 2.22 \mathrm{a}$ & $32.9 \pm 0.85 \mathrm{a}$ & $25.8 \pm 2.17 \mathrm{~b}$ \\
\hline Total carbohydrates & $123.4 \pm 17.30 \mathrm{~b}$ & $118.5 \pm 9.34 b$ & $166.7 \pm 7.78 \mathrm{a}$ & $131.6 \pm 2.42 b$ & $115.3 \pm 3.07 b$ \\
\hline Malic acid & $33.2 \pm 1.43 \mathrm{~b}$ & $47.7 \pm 3.92 \mathrm{a}$ & $33.1 \pm 1.90 \mathrm{~b}$ & $30.8 \pm 1.41 \mathrm{~b}$ & $33.9 \pm 1.73 \mathrm{~b}$ \\
\hline Cyan. 3-sophoroside & $9.0 \pm 0.31 \mathrm{c}$ & $12.9 \pm 2.10 \mathrm{~b}$ & $29.3 \pm 1.64 \mathrm{a}$ & $39.2 \pm 5.81 \mathrm{a}$ & $14.3 \pm 6.39 b$ \\
\hline Cyan. 3-gluc rutinoside & $107.9 \pm 1.90 \mathrm{~b}$ & $151.2 \pm 18.57 \mathrm{bc}$ & $235.1 \pm 7.83 \mathrm{a}$ & $190.3 \pm 21.43 \mathrm{ab}$ & $112.8 \pm 19.25 \mathrm{c}$ \\
\hline Cyan. 3-rutinoside & $4.5 \pm 0.16 b$ & $7.3 \pm 1.68 b$ & $12.3 \pm 0.28 \mathrm{a}$ & $11.96 \pm 1.73 \mathrm{a}$ & $5.5 \pm 1.39 \mathrm{~b}$ \\
\hline Peonidin 3-rutinoside & $31.6 \pm 1.10 \mathrm{~b}$ & $59.3 \pm 9.35 \mathrm{a}$ & $68.1 \pm 1.38 \mathrm{a}$ & $55.9 \pm 8.00 \mathrm{a}$ & $34.6 \pm 4.70 \mathrm{~b}$ \\
\hline Cyan. 3-glucoside & $3.6 \pm 0.15 \mathrm{~b}$ & $3.9 \pm 0.60 \mathrm{~b}$ & $5.3 \pm 0.18 \mathrm{a}$ & $3.9 \pm 0.61 \mathrm{~b}$ & $3.0 \pm 0.28 \mathrm{~b}$ \\
\hline Total anthocyanins & $156.6 \pm 3.47 \mathrm{c}$ & $234.6 \pm 32.16 \mathrm{bc}$ & $350.1 \pm 11.11 \mathrm{a}$ & $301.2 \pm 36.61 \mathrm{ab}$ & $170.2 \pm 31.93 \mathrm{c}$ \\
\hline
\end{tabular}

The contents of carbohydrates and malic acid was reported as $\mathrm{mg} \cdot \mathrm{g}^{-1} \mathrm{FW}$. The anthocyanins content was expressed as mg per $100 \mathrm{~g}$ FW.

accounted for the bulk of the organic acid content of sour cherry flesh of all genotypes; therefore, only the contents of malic acid are shown. The malic acid content of the flesh of fruit from all trees investigated ranged from 26.7 to $48.4 \mathrm{mg} \cdot \mathrm{g}^{-1} \mathrm{FW}$, with a mean of 33.6 mg. $\mathrm{g}^{-1}$ FW (Fig. 3). Both the geographical location and genotype affected the content of malic acid (Tables 1 and 2).

The total anthocyanin content and the content of the main individual anthocyanins in the flesh were determined (Fig. 4A-F). The five anthocyanins were cyanidin 3-sophoroside, cyanidin 3-rutinoside, peonidin 3-rutinoside, cyanidin 3-glucoside, and cyanidin 3-glucosyl-rutinoside (Fig. 4B-F). Cyanidin 3 -glucosyl-rutinoside accounted for $\approx 67 \%$ of the total anthocyanins, ranging from 39.5 to $270.8 \mathrm{mg}$ per $100 \mathrm{~g} \mathrm{FW}$ (Fig. 4B). There were also significant variations in the contents of the other anthocyanins. The total content of anthocyanins ranged from 61.0 to $383.4 \mathrm{mg}$ per $100 \mathrm{~g} \mathrm{FW}$ (Fig. 4A). Cyanidin 3 -glucoside and cyanidin 3-rutinoside were the least abundant and represented, on average, $2 \%$ and $3 \%$ of the total content, respectively (Fig. 4C and F). Peonidine 3rutinoside (mean, $37.9 \mathrm{mg}$ per $100 \mathrm{~g} \mathrm{FW}$ ) and cyanidin 3-sophoroside (mean, $12.6 \mathrm{mg}$ per $100 \mathrm{~g} \mathrm{FW}$ ) represented, on average, $21 \%$ and $7 \%$ of the total anthocyanin content, respectively. However, this varied considerably between fruit $(\approx 82 \%$ and $97 \%$, respectively) (Fig. 4D and E). The types of anthocyanins and their individual amounts in the flesh of fruit of genotypes grown in the Amerini Hills were similar to those described; the mean value of the total anthocyanins was $142.4 \mathrm{mg}$ per $100 \mathrm{~g} \mathrm{FW}$ (Table 1). Therefore, cyanidin 3-glucosylrutinoside and peonidine 3-rutinoside were the most abundant, contributing $68 \%$ and $23 \%$, respectively, to the total anthocyanins. Cyanidin 3-sophoroside, cyanidin 3-rutinoside, and cyanidin 3-glucoside represented $\approx 5 \%, 3 \%$, and $2 \%$ of the total anthocyanins, respectively (Table 1$)$. The total anthocyanin content of the flesh of fruit from the same genotype grown in different locations was high (mean, $242.5 \mathrm{mg}$ per $100 \mathrm{~g}$ FW). Cyanidin 3-glucosyl-rutinoside repre- sented $\approx 66 \%$ of this total (mean, $159.5 \mathrm{mg}$ per $100 \mathrm{~g} \mathrm{FW}$; range, 107.9 to $235.1 \mathrm{mg}$ per 100 g FW) (Table 2). Peonidine 3-rutinoside had a mean value of $55.9 \mathrm{mg}$ per $100 \mathrm{~g} \mathrm{FW}$, which was $23 \%$ of the total. Cyanidin 3sophoroside accounted for $8.6 \%$ of the total anthocyanins (mean, $20.9 \mathrm{mg}$ per $100 \mathrm{~g} \mathrm{FW}$ ). Cyanidin 3-rutinoside and cyanidin 3-glucoside were the least abundant compounds, with mean values of 8.3 and $3.9 \mathrm{mg}$ per 100 g FW, respectively (Table 2).

\section{Discussion}

Current agriculture uses a limited proportion of the globally available biodiversity of edible plants. A useful reservoir of such biodiversity is represented by plant species and cultivars that were used in the past, when less specialized farming systems were available (da Silva Dias, 2015). The recovery and use of this neglected and forgotten germplasm can be beneficial for the rural economy and the conservation of biodiversity, thus leading to more variable and richer nutrition for consumers and fostering new products for the agroindustry sector. To reintroduce neglected species and cultivars into profitable economic systems, it is necessary to know the characteristics of the product, which are relevant in terms of nutritional composition for direct consumption and/or industrial transformation. Prunus cerasus L. var. austera has a long history of being grown for its fruit. Its use is even documented in Renaissance art, such as in the "Annunciation" oil painting by Vincenzo Pagani (dated 1532) that includes sour cherry fruits; this painting is on display in the Ducal Palace in Urbino (Marche region of Italy). However, the industrialization of agriculture relegated this species to marginal use. Recently, there has been renewed interest in this crop because of the potential use of its fruit in traditional and health-promoting products (Alba et al., 2019). This has stimulated interest in acquiring knowledge about the composition and nutritional characteristics of the fruit, for which little information is available (Grafe and Schuster, 2014; Kołodziejczyk et al., 2013; Papp et al., 2010; Siddiq et al., 2011;
Vuletić et al., 2017). The aim of the present study was to decrease this gap by providing data regarding several compositional and nutritional characteristics of the fruit of a large number of trees and genotypes of Prunus cerasus L. var. austera grown in different areas or under growing conditions in central Italy. The results showed large variability among all characteristics considered and great influence due to both genotype and growing conditions.

Fruit weight affects the cost of harvesting, consumer desirability, and the processing of a crop into fruit products (Grafe and Schuster, 2014). Increased fruit weight is a characteristic of the domestication of fruit crops and is controlled by a complex interaction of environmental and genetic factors (Olmstead et al., 2007). In general, fruit of sour cherry genotypes are smaller than those of sweet cherry (Grafe and Schuster, 2014; Rakonjac et al., 2010; Rodrigues et al., 2008), and this has been linked to a lesser degree of domestication. The fresh weights of fruit from trees in the present study were in the range reported for sour cherry, and those from some genotypes were similar to those of smaller fruited sweet cherry cultivars (Grafe and Schuster, 2014; Rakonjac et al., 2010; Rodrigues et al., 2008) (Fig. 1A). Both the genotype and growing environment affected fruit size, thereby indicating the possibility of improving this important trait by breeding and the application of proper growing conditions.

The DM content of fruit is a key quality parameter, and it varies considerably during fruit development and between fruit of different species (Grafe et al., 2009). Various types of components can contribute to the DM of fruit (Grafe et al., 2009). In fruit that does not accumulate fat, the DM is usually $15 \%$ to $30 \%$ of the fresh weight (Escribano et al., 2017). In the present study, the DM content of the flesh of the sour cherry genotypes was also high when compared to that of sweet cherry (Alrgei et al., 2014; Escribano et al., 2017; Grafe et al., 2009). On average (i.e., the mean values of the genotypes studied), the main contributors to DM were glucose $(23.1 \%)$, fructose $(20.3 \%)$, sorbitol (13.6\%), and malic acid (18.8\%). 


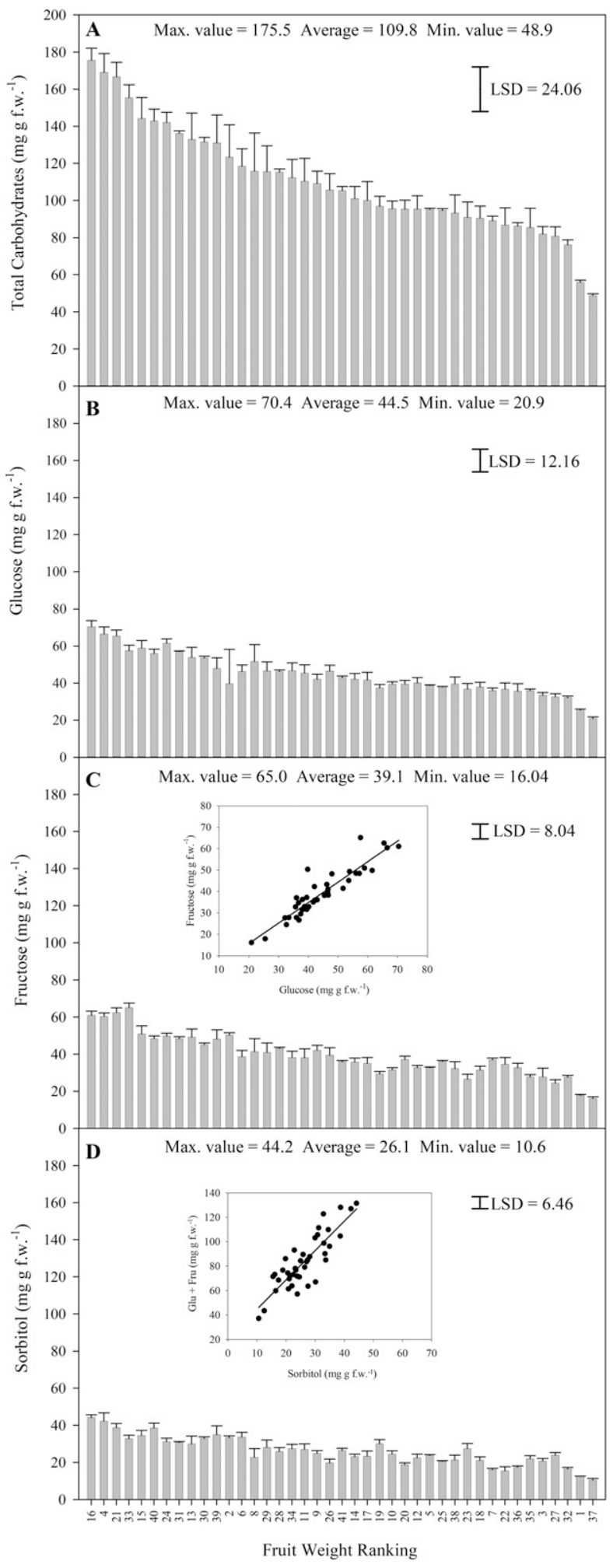

Fig. 2. Total carbohydrates (A), glucose (B), fructose (C), and sorbitol (D) contents in the flesh of sour cherry fruit collected in different geographical areas of the region of Umbria. Values represent the mean \pm SE. Data were analyzed according to a one-way analysis of variance. The bars indicate the least significant difference (LSD) between means according to Fisher's post-hoc test $(P \leq 0.05)$.

Glucose, fructose, and sorbitol together contributed an average of $57 \%$ to the DM of the fruit flesh (Supplemental Fig. 1). After combining the total nonstructural components that were measured, it was found that they comprised more than $75 \%$ of the DM, indicating that sour cherry fruit contains large amounts of metabolites of interest regarding its nutritional quality, sensory perception, and industrial transformation.

Fruit is a sink organ that imports most of its sugars via the phloem, and many species of Prunus, including sour cherry, import both sucrose and sorbitol (Gao et al., 2003). The accumulation of soluble sugars occurs mainly during phase III of fruit growth (Walker et al., 2011). The carbohydrate composition of sour cherry flesh resembles that of sweet cherry, but sucrose is absent (not detectable) in sour cherry, and sorbitol is more abundant than it is in sweet cherry (Gao et al., 2003; Walker et al., 2011). This indicates that sucrose is preferentially used for sink catabolism with regard to sorbitol. In fact, although the intake is mediated by a specific expression of a sorbitol transporter, sorbitol accumulation is favored by the lack of efficient catabolism as a result of the low abundance of the sorbitol-catabolizing enzyme sorbitol dehydrogenase (Gao et al., 2003). The results of the present study indicate that for Morello cherries, both genotype and environment have a significant influence on both the absolute and relative amounts of glucose, fructose, and sorbitol. There was large variability in the relative contents of hexoses and sorbitol, which have different organoleptic and nutritional characteristics, roles, and outcomes with technological transformation. Hexoses are sweeter than sorbitol per unit of mass and have a wider, direct, and complex impact on human health (Rippe and Angelopoulos, 2015). S. cerevisiae ferments hexoses, but not sorbitol, to ethanol (Parrou et al., 1997). Sorbitol, but not hexose, is a prebiotic because it differentially stimulates the Lactobacillus genera (Succi et al., 2017). Sorbitol has low cariogenic potential (Burt, 2006) and exerts an osmotic effect, retaining water in the intestine, thereby affecting the feces water content. Hence, the hexose-to-sorbitol ratio is a relevant parameter that can affect the taste and nutritional quality of transformed products. In Italy, for example, sour cherry is traditionally added to red wine to produce an aromatized alcoholic beverage called visner, and the quality of this product, and that of similar preparations, can likely be modulated using sour cherry with different ratios of hexose to sorbitol. Furthermore, among the MSC, the concentration of sorbitol is most closely linked to the flesh DM content (Supplemental Table 2). The large variability in the soluble sugar contents and composition (i.e., hexoseto-sorbitol ratio) of Morello cherry flesh can be used as a tool to modulate the quality, taste, and nutritional characteristics of the transformed products. Producers and the industrial sector can take advantage of the variability of the carbohydrate content linked to the different combinations of genotypes and growing conditions when deciding on the use (as fresh or different types of processed products) of sour cherries. In this regard, the hexose-to-sorbitol ratio is a valuable index for the nutritional and quality characterization of food products derived from sour cherry.

The organic acid content of fruit has a major effect on its organoleptic properties and its processing into fruit products. The predominant organic acid in both sour and sweet cherries is malic acid (Ballistreri et al., 2013; Rodrigues et al., 2008; Stéger Máté, 


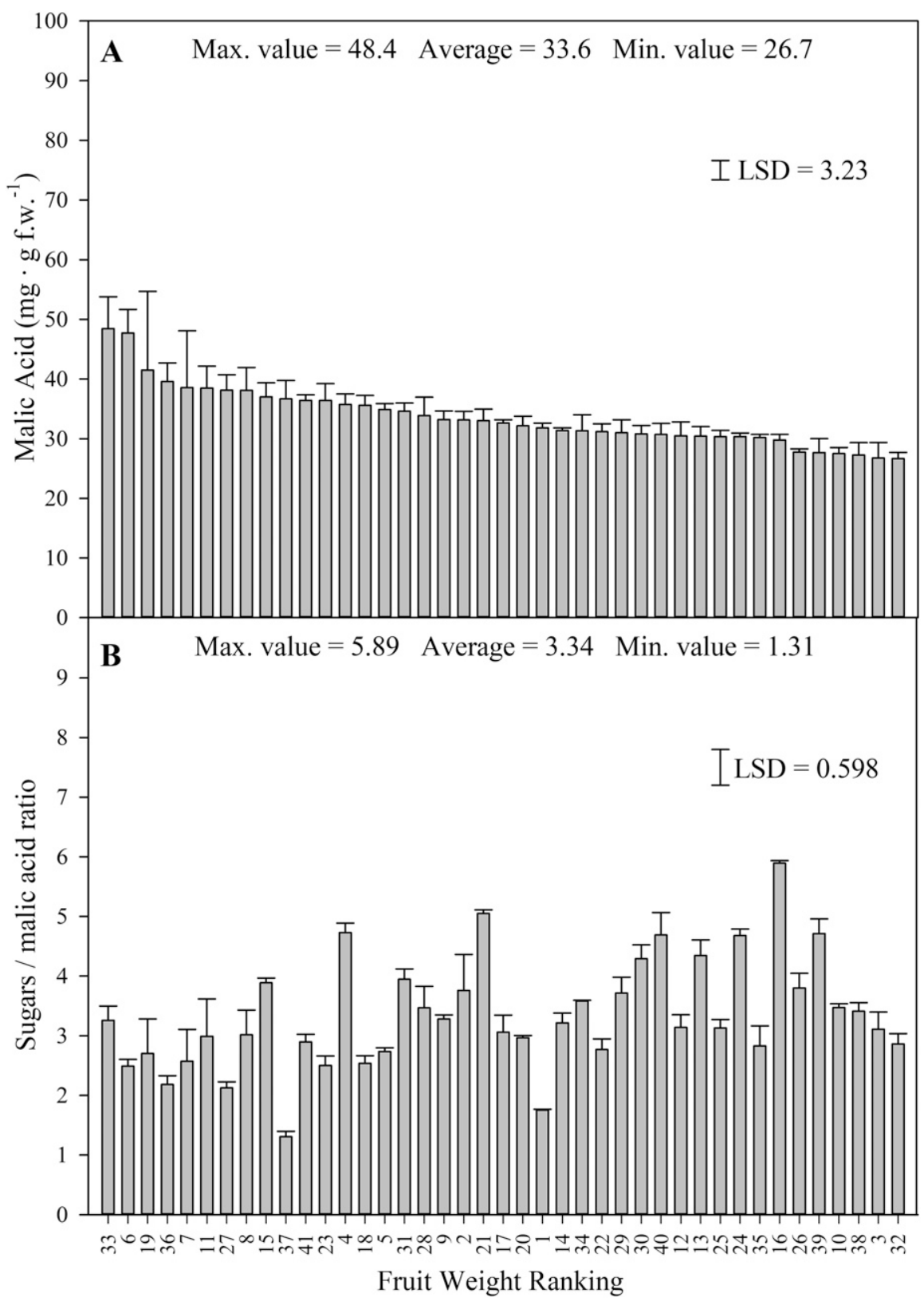

Fig. 3. Malic acid content (A) and sugar-to-malate ratio (B) in the flesh of sour cherry fruit collected in different geographical areas of the region of Umbria. Values represent the mean \pm SE. Data were analyzed according to a one-way analysis of variance (ANOVA). The bars indicate the least significant difference (LSD) between means according to Fisher's post-hoc test $(P \leq 0.05)$.

2012; Usenik et al., 2008; Walker et al., 2011). Nevertheless, only partial research of the organic acid content of sour cherry has been performed. Several reports have determined titratable acidity but not the content of each specific organic acid (Füzfai et al., 2004). Others have focused on sour cherry juice because often it is not possible to calculate the content in the flesh; in addition, many studies have not unequivocally defined the type of sour cherry fruit that was analyzed (i.e., caproniana, marasca, and austera), but large differences in the acid content of the different types can be expected (Grafe and Schuster, 2014). Furthermore, contrasting data exist regarding the content of organic acids in sour cherry fruit, even for the same cultivars. Füzfai et al. (2004) reported that malic acid contents of the fruit of the "authentic sour cherry" cultivars Érdi bötermö and Kántorjánosi were 12.7 and $15.3 \mathrm{mg} \cdot \mathrm{g}^{-1}$ $\mathrm{FW}$, respectively (these values were calculated because their contents were expressed as the percentage of the DM); the content in the flesh of citric, quinic, and stearic acids were approximately two orders of magnitude lower than that of malic acid, and tartaric acid was not reported. In contrast, for Érdi bötermö and Kántorjánosi (indicated as Kántor jánosi 3), Ficzec et al. (2015) reported that malic acid contents at optimal harvest time were 2.5 and $3.8 \mathrm{mg} \cdot \mathrm{g}^{-1} \mathrm{FW}$, respectively, and that the contents of succinic acid and tartaric acid were approximately half that of malic acid. In our samples (analyzed by ion-exchange chromatography), the contents of acids other than malic were very low or undetectable. The malate content of sour cherry fruit (26.7$48.4 \mathrm{mg} \cdot \mathrm{g}^{-1} \mathrm{FW}$ ) found in the present study was higher than that reported in the literature, and even higher than that reported by Füzfai et al. (2004). Walker et al. (2011) found that in sweet cherry (cv. Durone Nero II), malic acid accumulates mainly during phase III of growth, reaching a peak concentration of 8 $\mathrm{mg} \cdot \mathrm{g}^{-1} \mathrm{FW}$, and that a small decrease in its concentration in ripe fruit was due to dilution but not to dissimilation. Ficzec et al. (2015) showed minor changes in malic acid during the pre-ripening and post-ripening periods. The average malic acid content of germplasm collections of sweet cherry has been reported to vary from 5.7 to $8.8 \mathrm{mg} \cdot \mathrm{g}^{-1} \mathrm{FW}$, with a minimum value of $3.5 \mathrm{mg} \cdot \mathrm{g}^{-1} \mathrm{FW}$ and a maximum value of $14.1 \mathrm{mg} \cdot \mathrm{g}^{-1} \mathrm{FW}$ (Ballistreri et al., 2013; Usenik et al., 2008). The results of the present study indicated that Morello sour cherry has considerably higher levels of malic acid than do sweet cherry and other sour cherry cultivars studied so far.

The ratio of sugars to organic acids is an important parameter in terms of taste, consumer acceptance, and processing into fruit products (Famiani et al., 2015). Sour cherries with a high sugar-to-acid ratio can be suitable for direct consumption, whereas those with a low sugar-to-acid ratio are better suited for processing into fruit products (Papp et al., 2010). The data of a survey regarding sweet cherry cultivars (Table 3 in Ballistreri et al., 2013) indicated an average sugar (glucose + fructose + sorbitol)-to-malic acid ratio of 20.9, with a minimum value of 14.7. Füzfai et al. (2004) analyzed "authentic sour cherry" and found an average sugar-tomalic acid ratio of 7.9 , with small variations between cultivars. Higher values of this ratio for sour cherry were reported by Ficzec et al. (2015) (average value, 21.9; range, 14.730.2) (recalculated using data regarding optimal picking time from Table 6 of this article). Interestingly, in Italy, the sour cherries of the Morello type, named "visciola," have been traditionally used only for processing into fruit products. This is because of the low sugar-to-malate ratio found during our study (mean, 3.3; range, 1.3-5.6) (Fig. 3B), and it is a relevant aspect in terms of quality-related fruit market destinations (Famiani et al., 2015).

Various health-promoting qualities have been attributed to the consumption of cherries and their products because they appear to have protective action against serious illnesses (McCune et al., 2011) by reducing markers for oxidative stress and inflammation and by improving sleep, cognitive function, and recovery from pain after heavy exercise (Kelley et al., 2018). Many of these effects of cherries have been linked to the presence of antioxidant compounds, particularly polyphenols (including anthocyanins) (McCune et al., 2011; Kelley et al., 2018). The sour cherry antioxidant capacity is largely dependent on its polyphenol content, and, in cherry, the most abundant polyphenols are represented by anthocyanins (Alba et al., 2019). The cyanidin 


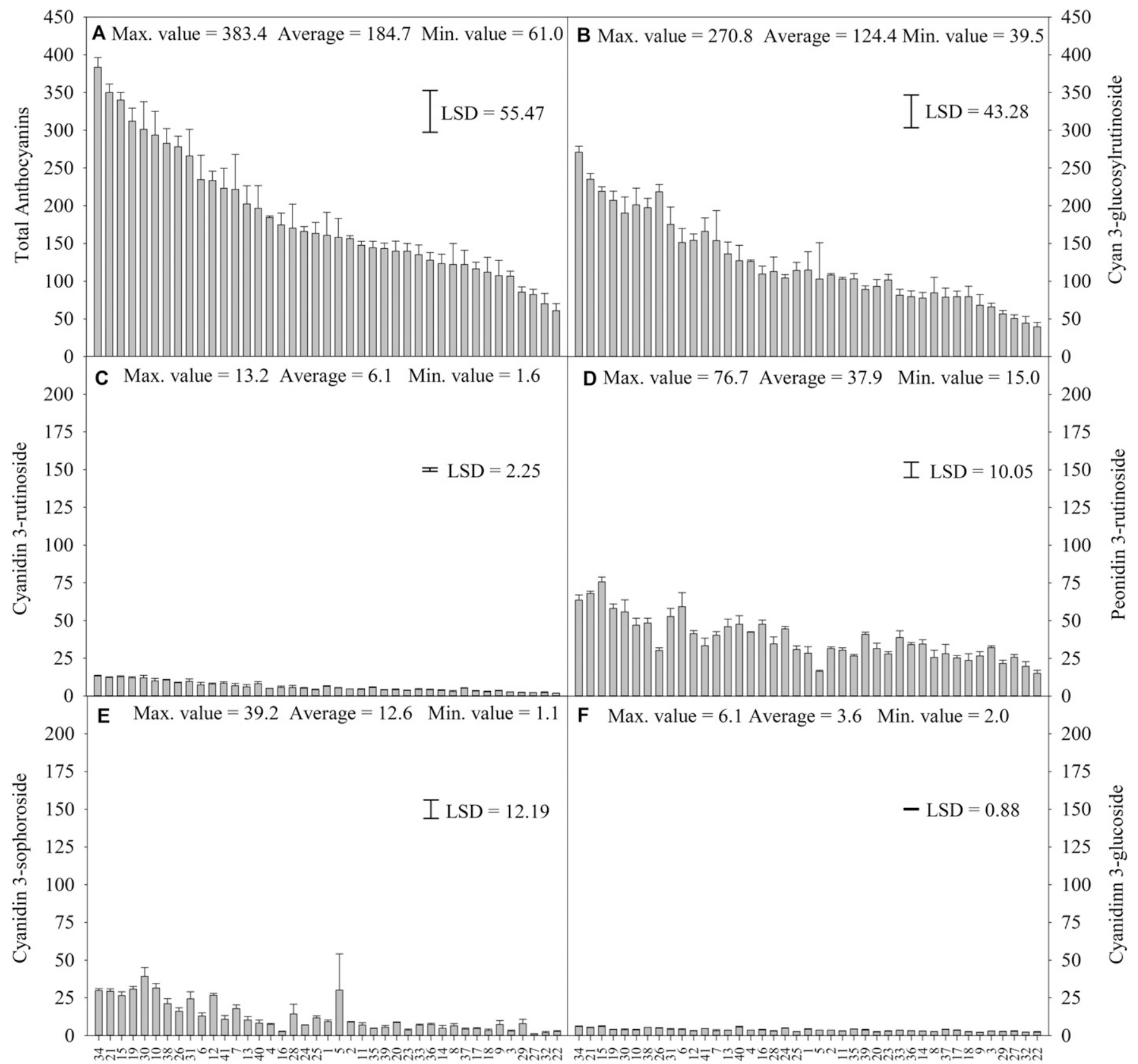

Fruit Weight Ranking

Fruit Weight Ranking

Fig. 4. Anthocyanin composition (A-F) in the flesh of sour cherry fruit collected in different geographical areas of the region of Umbria. Values represent the mean \pm SE. Data were analyzed according to a one-way analysis of variance (ANOVA). The bars indicate the least significant difference (LSD) between means according to Fisher's post-hoc test $(P \leq 0.05)$.

3-glucosyl rutinoside, a specific sour cherry anthocyanin (Blando et al., 2004), was the most abundant anthocyanin regardless of the genetic and environmental effects. This is relevant in terms of the effect of the transformation process because cyanidin 3glucosyl-rutinoside appears to be more easily extractable and more stable than other anthocyanins in other fruit types (McDougall, 2005; Toydemir et al., 2013).

\section{Conclusions}

The sour cherry trees sampled in this work were tested genetically and were unequivocally attributed to the Prunus cerasus species and botanical cultivar austera (Gaudet et al., 2018). Hence, we can infer that the high malate content and low sugar-to-malate ratio (lower than any other published value for sour cherry) are distinctive nutritionally related quality characteristics of Morello cherries. All fruit compositional parameters (weight, DM contents, carbohydrates, malic acid, and anthocyanins) showed large variability that was affected by both the genotype and growing environment. The results indicated that the soluble sugars (glucose + fructose + sucrose)-to-sorbitol ratio could be used as an index to decide the best use for the fruit. Fruit with a high soluble sugar-tosorbitol ratio can be preferentially used for jelly or fermented beverages. Fruit with a low soluble sugars-to-sorbitol ratio, particularly due to high sorbitol, might be used to produce functional food with laxative properties. Overall, the results show that Italy possesses a valuable germplasm reservoir for Morello cherries, and different genotypes could be useful for producing cherries that can be exploited to respond to the market requirements for products that recall tradition and offer high-quality standards in terms of taste, appearance, nutritional quality, and health. The genotypes that were evaluated should be propagated and planted in a collection field to maintain them and, possibly, use them as mother plants for propagation. 


\section{Literature Cited}

Alba, C.M.A., M. Daya, and C. Franck. 2019. Tart cherries and health: Current knowledge and need for a better understanding of the fate of phytochemicals in the human gastrointestinal tract. Crit. Rev. Food Sci. Nutr. 59(4):626-638.

Alrgei, H.O.S., D.Č. Dabić, M.M. Natić, V.S. Rakonjac, D. Milojković-Opsenica, Ž.L. Tešić, and M. Milica. 2014. Chemical profile of major taste- and health-related compounds of Oblačinska sour cherry. J. Sci. Food Agr. 96:1241-1251

Ballistreri, G., A. Continella, A. Gentile, M. Amenta, S. Fabroni, and P. Rapisarda. 2013. Fruit quality and bioactive compounds relevant to human health of sweet cherry (Prunus avium L.) cultivars grown in Italy. Food Chem. 140:630-638.

Blando, F., C. Gerardi, and I. Nicoletti. 2004. Sour cherry (Prunus cerasus L.) anthocyanins as ingredients for functional foods. BioMed. Res. Inter. 5:253-258.

Burt, B.A. 2006. The use of sorbitol-and xylitolsweetened chewing gum in caries control. J. Amer. Dent. Assoc. 137:190-196.

Chaovanalikit, A. and R.E. Wrolstad. 2004. Total anthocyanins and total phenolics of fresh and processed cherries and their antioxidant properties. J. Food Sci. 69:FCT 67-72.

da Silva Dias, J.C. 2015. Biodiversity and plant breeding as tools for harmony between modern agriculture production and the environment, $\mathrm{p}$. 3-44. In: M. Caliskan (ed.). Molecular approaches to genetic diversity. InTechOpen.

Di Matteo, A., R. Russo, G. Graziani, A. Ritieni, and C. Di Vaio. 2016. Characterization of autochthonous sweet cherry cultivars (Prunus avium L.) of southern Italy for fruit quality, bioactive compounds and antioxidant activity. J. Sci. Food Agr. 97(9):2782-2794.

Di Vaio, C., N. Marallo, G. Graziani, A. Ritieni, and A. Di Matteo. 2015. Evaluation of fruit quality, bioactive compounds and total antioxidant activity of flat peach cultivars. J. Sci. Food Agr. 95(10):2124-2131.

Escribano, S., W.V. Biasi, R. Lerud, D.C. Slaughter, and E.J. Mitcham. 2017. Non-destructive prediction of soluble solids and dry matter content using NIR spectroscopy and its relationship with sensory quality in sweet cherries. Postharvest Biol. Technol. 128:112120.

Famiani, F., A. Battistelli, S. Moscatello, J.G. Cruz-Castillo, and R.P. Walker. 2015. The organic acids that are accumulated in the flesh of fruits: Occurrence, metabolism and factors affecting their contents-a review. Rev. Chapingo Ser. Hortic. 21:97-128.

Faniadis, D., P.D. Drogoudi, and M. Vasilakakis. 2010. Effects of cultivar, orchard elevation, and storage on fruit quality characters of sweet cherry (Prunus avium L.). Scientia Hort. 125:301-304.

FAOSTAT. 2017. Food and Agriculture Organization of the United Nations. Food and agriculture data. $<$ http://www.fao.org/faostat/en/\#data>.

Ficzek, G., M. Ladányi, G. Végvári, and M. Tóth. 2015. Mathematical modelling of the accumulation of carbohydrates and organic acids throughout the ripening process of Hungarian sour cherry cultivars. Trees 29:797-807.

Füzfai, Z., Z.F. Katona, E. Kovács, and I. Molnár-Perl. 2004. Simultaneous identification and quantification of the sugar, sugar alcohol, and carboxylic acid contents of sour cherry, apple, and ber fruits, as their trimethylsilyl derivatives, by gas chromatography-mass spectrometry. J. Agr. Food Chem. 52:7444-7452.

Gao, Z., L. Maurousset, R. Lemoine, S.D. Yoo, S. Van Nocker, and W. Loescher. 2003. Cloning, expression, and characterization of sorbitol transporters from developing sour cherry fruit and leaf sink tissues. Plant Physiol. 131:1566-1575.

Gaudet, M., F. Villani, M. Cherubini, I. Beritognolo, I. Dalla Ragione, S. Proietti, and C. Mattioni. 2018. Genetic diversity and molecular fingerprinting of Prunus cerasus var. austera from central Italy. Plant Biosyst. 1-7, doi. 10.1080/ 11263504.2018.1498403.

Gonçalves, B., A.P. Silva, J. Moutinho-Pereira, E. Bacelar, E. Rosa, and A.S. Meyer. 2007. Effect of ripeness and postharvest storage on the evolution of colour and anthocyanins in cherries (Prunus avium L.). Food Chem. 103:976-984.

Grafe, C. and M. Schuster. 2014. Physicochemical characterization of fruit quality traits in a German sour cherry collection. Scientia Hort. 180:24-31.

Grafe, C., M. Hofer, and M. Schuster. 2009 Evaluation of dry matter in sour cherry (Prunus cerasus L.). Acta Hort. (839):281-286.

Kalt, W. 2006. Effects of production and processing factors on major fruit and vegetable antioxidants. J. Food Sci. 70:R11-R19.

Kelley, D.S., Y. Adkins, and K.D. Laugero. 2018 A review of the health benefits of cherries. Nutrients 10:368.

Kołodziejczyk, K., M. Sójka, M. Abadias, I. Viñas, S. Guyot, and A. Baron. 2013. Polyphenol composition, antioxidant capacity, and antimicrobial activity of the extracts obtained from industrial sour cherry pomace. Ind. Crops Prod. 51:279-288.

Marchese, A., D. Giovannini, A. Leone, R. Mafrica, M. Palasciano, C. Cantini, C. D Vaio, F.R. De Salvador, G. Giacalone, T. Caruso, and F.P. Marra. 2017. S-genotype identification, genetic diversity and structure analysis of Italian sweet cherry germplasm. Tree Genet. Genomes 13(5):93.

McCune, L.M., C. Kubota, N.R. Stendell-Hollis, and C.A. Thomson. 2011. Cherries and health: A review. Crit. Rev. Food Sci. Nutr. 51:1-12.

McDougall, G.J., P. Dobson, P. Smith, A. Blake, and D. Stewart. 2005. Assessing potential bioavailability of raspberry anthocyanins using an in vitro digestion system. J. Agr. Food Chem. 53(15):5896-5904.

Mikulic-Petkovsek, M., F. Stampar, R. Veberic, and H. Sircelj. 2016. Wild Prunus fruit species as a rich source of bioactive compounds. J. Food Sci. 81:C1928-C1937.

Olmstead, J.W., A.F. Iezzoni, and M.D. Whiting. 2007. Genotypic differences in sweet cherry fruit size are primarily a function of cell number. J. Amer. Soc. Hort. Sci. 132:697703.
Papapetros, S., A. Louppis, I. Kosma, S. Kontakos, A. Badeka, and M.G. Kontominas. 2018. Characterization and differentiation of botanical and geographical origin of selected popular sweet cherry cultivars grown in Greece. J. Food Compos. Anal. 72:48-56.

Papp, N., B. Szilvássy, L. Abrankó, T. Szabó, P. Pfeiffer, Z. Szabó, and A. Hegedűs. 2010. Main quality attributes and antioxidants in Hungarian sour cherries: Identification of genotypes with enhanced functional properties. Intl. J. Food Sci. Technol. 45:395-402.

Parrou, J.L., M.A. Teste, and J. François. 1997. Effects of various types of stress on the metabolism of reserve carbohydrates in Saccharomyces cerevisiae: Genetic evidence for a stress-induced recycling of glycogen and trehalose. Microbiology 143:1891-1900.

Rakonjac, V., M.F. Akšić, D. Nikolić, D. Milatović, and S. Colić. 2010. Morphological characterization of 'Oblačinska' sour cherry by multivariate analysis. Scientia Hort. 125(4):679-684.

Rippe, J.M. and T.J. Angelopoulos. 2015. Sugars and health controversies: What does the science say? Adv. Nutr. 6(4):493S-503S

Rodrigues, L.C., M.R. Morales, A.J.B. Fernandes, and J.M. Ortiz. 2008. Morphological characterization of sweet and sour cherry cultivars in a germplasm bank at Portugal. Genet. Resources Crop Evol. 55(4):593-601.

Siddiq, M., A. Iezzoni, A. Khan, P. Breen, A.M. Sebolt, K.D. Dolan, and R. Ravi. 2011. Characterization of new tart cherry (Prunus cerasus L.): Selections based on fruit quality, total anthocyanins, and antioxidant capacity. Intl. J. Food Prop. 14:471-480.

Stéger-Máté, M. 2012. Sweet and tart cherries, p. 433-446. In: N.K. Sinha, J.S. Sidhu, J. Barta, J.S.B. Wu, and M.P. Cano (eds.). Handbook of fruits and fruit processing. 2nd ed. WileyBlackwell.

Succi, M., P. Tremonte, G. Pannella, L. Tipaldi, A. Cozzolino, R. Romaniello, E. Sorrentino, and R. Coppola. 2017. Pre-cultivation with selected prebiotics enhances the survival and the stress response of Lactobacillus rhamnosus strains in simulated gastrointestinal transit. Front. Microbiol. 8:1067.

Toydemir, G., E. Capanoglu, M.V.G. Roldan, R.C. de Vos, D. Boyacioglu, R.D. Hall, and J. Beekwilder. 2013. Industrial processing effects on phenolic compounds in sour cherry (Prunus cerasus L.) fruit. Food Res. Intl. 53:218-225.

Usenik, V., J. Fabčič, and F. Stampar. 2008. Sugars, organic acids, phenolic composition and antioxidant activity of sweet cherry (Prunus avium L.). Food Chem. 107:185-192.

Vuletić, M.V., K. Dugalić, I. Mihaljević, V. Tomaš, D. Vuković, Z. Zdunić, B. Puškar, and Z. Jurković. 2017. Season, location and cultivar influence on bioactive compounds of sour cherry fruits. Plant Soil Environ. 63:389395.

Walker, R.P., A. Battistelli, S. Moscatello, Z.H. Chen, R.C. Leegood, and F. Famiani. 2011. Phosphoenolpyruvate carboxykinase in cherry (Prunus avium L.) fruit during development. J. Expt. Bot. 62:5357-5365. 
Supplemental Table 1. Ranking code, sampling code, clone identified, geographical localization, and geographical descriptors of plants collected from the Umbria region. ${ }^{2}$

\begin{tabular}{|c|c|c|c|c|c|c|}
\hline Fruit wt ranking & Sampling code & Area of the Umbria region & Municipality & Alt (m.s.l.) & Lat. N & Long. E \\
\hline 1 & 82 & Orvieto & Orvieto & 347 & $42^{\circ} 67^{\prime} 98^{\prime \prime}$ & $12^{\circ} 14^{\prime} 11^{\prime \prime}$ \\
\hline 3 & 38 & Orvieto & Orvieto & 309 & $42^{\circ} 72^{\prime} 00^{\prime \prime}$ & $12^{\circ} 11^{\prime} 18^{\prime \prime}$ \\
\hline 4 & 147 & Amerini Hills & Narni & 238 & $42^{\circ} 46^{\prime} 06^{\prime \prime}$ & $12^{\circ} 50^{\prime} 56^{\prime \prime}$ \\
\hline 6 & 14 & Orvieto & Ficulle & 465 & $42^{\circ} 83^{\prime} 2^{\prime \prime} 1^{\prime \prime}$ & $12^{\circ} 06^{\prime} 94^{\prime \prime}$ \\
\hline 7 & 12 & Orvieto & Porano & 397 & $42^{\circ} 69^{\prime} 76^{\prime \prime}$ & $12^{\circ} 10^{\prime} 75^{\prime \prime}$ \\
\hline 8 & 130 & Amerini Hills & Narni & 278 & $42^{\circ} 46^{\prime} 55^{\prime \prime}$ & $12^{\circ} 50^{\prime} 71^{\prime \prime}$ \\
\hline 11 & 27 & Orvieto & Allerona & 404 & $42^{\circ} 79^{\prime} 57^{\prime \prime}$ & $12^{\circ} 03^{\prime} 65^{\prime \prime}$ \\
\hline 12 & 89 & Upper Tiber Valley & Pietralunga & 688 & $43^{\circ} 50^{\prime} 18^{\prime \prime}$ & $12^{\circ} 47^{\prime} 23^{\prime \prime}$ \\
\hline 13 & 148 & Amerini Hills & Nami & 275 & $42^{\circ} 46^{\prime} 69^{\prime \prime}$ & $12^{\circ} 50^{\prime} 72^{\prime \prime}$ \\
\hline 14 & 48 & Orvieto & Castel Viscardo & 165 & $42^{\circ} 76^{\prime} 70^{\prime \prime}$ & $12^{\circ} 04^{\prime} 03^{\prime \prime}$ \\
\hline 15 & 100 & Upper Tiber Valley & Gubbio & 702 & $43^{\circ} 49^{\prime} 91^{\prime \prime}$ & $12^{\circ} 47^{\prime} 58^{\prime \prime}$ \\
\hline 16 & 125 & Valnerina & Fabro & 255 & $42^{\circ} 87^{\prime} 47^{\prime \prime}$ & $12^{\circ} 04^{\prime} 73^{\prime \prime}$ \\
\hline 17 & 101 & Orvieto & Norcia & 590 & $42^{\circ} 79^{\prime} 24^{\prime \prime}$ & $13^{\circ} 09^{\prime} 71^{\prime \prime}$ \\
\hline 23 & 71 & Orvieto & Orvieto & 139 & $42^{\circ} 74^{\prime} 10^{\prime \prime}$ & $12^{\circ} 09^{\prime} 10^{\prime \prime}$ \\
\hline 24 & 102 & Valnerina & Norcia & 590 & $42^{\circ} 79^{\prime} 20^{\prime \prime}$ & $13^{\circ} 09^{\prime} 70^{\prime \prime}$ \\
\hline 25 & 16 & Orvieto & Ficulle & 453 & $42^{\circ} 83^{\prime} 30^{\prime \prime}$ & $12^{\circ} 06^{\prime} 66^{\prime \prime}$ \\
\hline 26 & 65 & Orvieto & Castel Giorgio & 540 & $42^{\circ} 71^{\prime} 12^{\prime \prime}$ & $11^{\circ} 98^{\prime} 10^{\prime \prime}$ \\
\hline 27 & 70 & Orvieto & Orvieto & 131 & $42^{\circ} 74^{\prime} 03^{\prime \prime}$ & $12^{\circ} 09^{\prime} 51^{\prime \prime}$ \\
\hline 28 & 56 & Orvieto & Castel Giorgio & 500 & $42^{\circ} 70^{\prime} 43^{\prime \prime}$ & $11^{\circ} 98^{\prime} 03^{\prime \prime}$ \\
\hline 29 & 123 & Orvieto & Fabro & 319 & $42^{\circ} 86^{\prime} 50^{\prime \prime}$ & $12^{\circ} 01^{\prime} 15^{\prime \prime}$ \\
\hline 30 & 97 & Orvieto & Gubbio & 608 & $43^{\circ} 48^{\prime} 20^{\prime \prime}$ & $12^{\circ} 49^{\prime} 68^{\prime \prime}$ \\
\hline 31 & 99 & Upper Tiber Valley & Gubbio & 584 & $43^{\circ} 49^{\prime} 46^{\prime \prime}$ & $12^{\circ} 47^{\prime} 53^{\prime \prime}$ \\
\hline 32 & 28 & Upper Tiber Valley & Orvieto & 447 & $42^{\circ} 70^{\prime} 92^{\prime \prime}$ & $12^{\circ} 06^{\prime} 14^{\prime \prime}$ \\
\hline 33 & 2 & Orvieto & Orvieto & 317 & $42^{\circ} 70^{\prime} 85^{\prime \prime}$ & $12^{\circ} 08^{\prime} 12^{\prime \prime}$ \\
\hline 34 & 92 & Upper Tiber Valley & Pietralunga & 596 & $43^{\circ} 48^{\prime} 42^{\prime \prime}$ & $12^{\circ} 49^{\prime} 47^{\prime \prime}$ \\
\hline 35 & 67 & Orvieto & Orvieto & 445 & $42^{\circ} 70^{\prime} 84^{\prime \prime}$ & $12^{\circ} 05^{\prime} 80^{\prime \prime}$ \\
\hline
\end{tabular}

${ }^{\mathrm{z}}$ The fruit weight ranking (1-41) identifies plants based on the fresh fruit weight; ranking is from heavier (1) to lighter (41). The sampling code is the original sampling code used during field sampling procedures.

Supplemental Table 2. Pearson's correlation coefficient for flesh dry matter (\%) and sugar contents of sour cherry fruits.

\begin{tabular}{lllll}
\hline & DM \% & Glucose & Fructose & Sorbitol \\
\hline DM \% & 1.00 & & & \\
Glucose & $0.62^{* *}$ & 1.00 & & \\
Fructose & $0.51^{* *}$ & $0.95^{* *}$ & 1.00 & 1.00 \\
Sorbitol & $0.78^{* *}$ & $0.89^{* *}$ & $0.82^{* *}$ & $0.92^{* *}$ \\
Total sugars & $0.64^{* *}$ & $0.99^{* *}$ & $0.97^{* *}$ & 1.00 \\
\hline
\end{tabular}




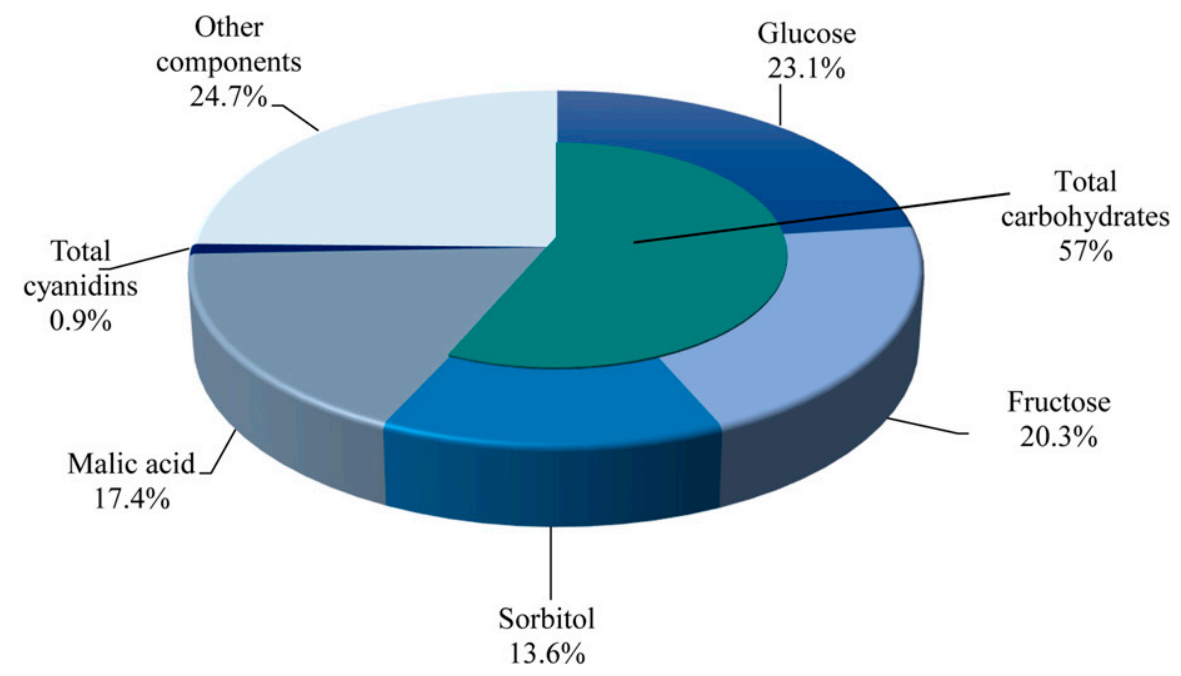

Supplemental Fig. 1. Pie chart showing the percentage contribution of different metabolites and the total sugars to the dry matter content of sour cherry fruits. 